\title{
PHYTOCHEMICAL AND BIOLOGICAL STUDY OF GREVILLEA ROBUSTA A. CUNN CULTIVATED IN EGYPT
}

\author{
Amany Sayed Ahmed
}

Department of Pharmacognosy, Faculty of Pharmacy, Assiut University, Assiut, Egypt

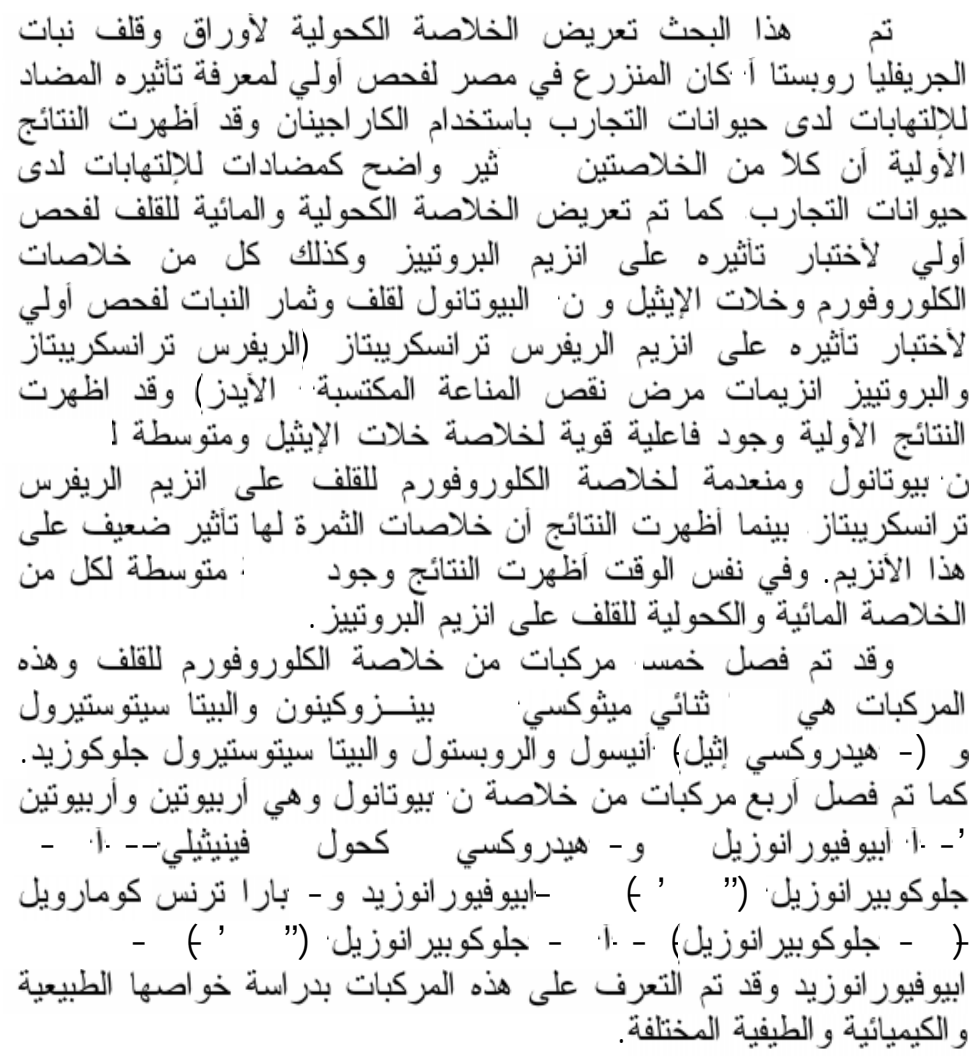

The alcoholic extracts of the leaves and bark of Grevillea robusta A.Cunn cultivated in Egypt were subjected to preliminary anti-inflammatory screening. The results showed that, the alcoholic extracts showed a significant anti-inflammatory activity using carrageenan-induced edema. The alcoholic and aqueous extracts of the bark were tested as anti-HIV-1 protease, where they showed 
a moderate HIV-1 protease (1 PR) inhibitory activity at conc. 200 $\mu \mathrm{g} / \mathrm{ml}$. The ethyl acetate fraction of the bark showed a significant HIV-RT inhibitory activity, the n-butanol fraction showed a moderate activity, while the chloroform fraction showed no activity at conc. $200 \mu \mathrm{g} / \mathrm{ml}$. On the other hand the chloroform and ethyl acetate fractions of the fruit showed a weak HIV-RT inhibitory activity. From the chloroform-soluble fraction of the total alcohol extract of the bark 2,6-dimethoxy-1,4-benzoquinone, $\beta$-sitosterol, 4-(1-hydroxy ethyl) anisol, robustol and $\beta$-sitosterol glucoside were isolated. Four phenolic glycosides were isolated from the nbutanol-soluble fraction of the bark and identified as arbutin, arbutin 2'-O- $\beta$-apiofuranoside, 4-hydroxyphenethyl alcohol 8-O- $\beta$ apiofuranosyl $\left(1^{\prime \prime} \rightarrow 2^{\prime}\right)$ - $\quad \beta$-glucopyranoside and 4-O-trans- $p$ coumaroyl $\beta$-glucopyranoside 8 8-O- $\beta$-apiofuranosyl- $\left.\left(1^{\prime \prime} \rightarrow 6^{\prime}\right)\right\}$-O$\beta$-glucopyranosyl. The identification of the isolated compounds was carried out using different methods including physical, chemical and spectral analysis.

\section{INTRODUCTION}

Genus Grevillea (F. Proteaceae) comprises about 190 species. Some of them yield useful timber. The natives of North-West Australia were observed to use the sap of two species of Grevillea to scarify their bodies. G.robusta A.Cunn (Australian silky oak), also often called silver-oak, is used to line streets for shade purposes and in Los Angels "Grevillea poisoning" is well known to telephone linemen and pruners. It has been planted extensively in India and Sri Lanka as a shade for tea, and in Hawaii and Brazil as a shade for coffee. ${ }^{1-3}$ Recently, G.robusta extract showed leishmanicidal activity. ${ }^{4}$

Previous study on the leaves, flowers and fruits of the plant resulted in isolation and identification of polyalkylphenols, cinnamic acid and arbutin derivatives, flavonoids, and gallic acid derivatives. ${ }^{5-7}$ The presence of such biologically active compounds encourages the study of different extracts of the bark of the plant.

In this paper, upon fractionation of the total alcoholic extract of Grevillea robusta A.Cunn bark, nine compounds were isolated and identified.

\section{EXPERIMENTAL}

\section{General}

M.p and m.m.p on Stuart Scientific (SMP 1, England). IR spectra $(\mathrm{KBr})$ were measured on JASCO FT/IR-5300 spectrophotometer. The ${ }^{1} \mathrm{H}$ and ${ }^{13} \mathrm{C}$-NMR spectra were obtained on JEOL, JMS (500, $300 \mathrm{MHz}$ for ${ }^{1} \mathrm{H}$ and $125,75 \mathrm{MHz}$ for ${ }^{13} \mathrm{CNMR}$ ) using TMS as internal standard. EIMS spectra was obtained with a Jeol JMS- $500 \quad \mathrm{~T}$ mass spectrometer. TLC analyses were 
performed on silica gel $60 \mathrm{~F}_{254}$ and RP-18 $\mathrm{F}_{254} \mathrm{~S}$ (E. Merck, Darmastadt) precoated plates, detection was done $\begin{array}{llllll}\text { by spraying with } 10 \% & \mathrm{H}_{2} \mathrm{SO}_{4}\end{array}$ followed by heating at $110^{\circ}$. For medium-pressure liquid chromatographic separation a LiChroprep C-18 (Merck) material was used. Silica gel 60 (60-120 mesh) and Diaion (Nippon Rensui Co.) were utilized for open column chromatography (CC). Sephadex LH-20 (Fluka) was used also for fine separations.

Analytical HPLC (for HIV-1 PR inhibitory activity): Shimadzu, Recorder: C-R6 Achromatopac, Pump: LC-9A. Detector: SPD-6A UV spectrophotometric. Column: RP col. $(4.6 \times 150 \mathrm{~mm})$ (AP-302S-5 300AODS). Incubator: Bioshaker BR-30L. flow rate; $1 \mathrm{ml} / \mathrm{min}$. Solvent A: $1 \%$ TFA (trifluoroacetic acid in $\mathrm{H}_{2} \mathrm{O}$ ), Solvent B: $\mathrm{CH}_{3} \mathrm{CN}$. Range detector: 0.005 .

The following solvent systems were used: $\mathrm{CHCl}_{3}-\mathrm{MeOH}$ (4:1, 9:1), n-BuOH-Acetic acid- $\mathrm{H}_{2} \mathrm{O}(4: 1: 2)$ and $\mathrm{MeOH}-\mathrm{H}_{2} \mathrm{O}(1: 1,3: 2)$.

\section{Chemicals}

A- Authentics: $\quad \beta$-sitosterol, $\quad \beta$ sitosterol glucoside, glucose, apiose, robustol, $p$-coumaric acid, hydro-quinone and arbutin, were obtained from Pharmacognosy Dept., Faculty of Pharmacy, Assiut University, Assiut, Egypt.

B- HIV-RT (Eiken Chemicals Co.Ltd., Osaka, Japan), Peptide (Poly(rA) $)_{n}-\mathrm{p}(\mathrm{dT})_{12-18}$ ) (Pharmacia, Uppsala, Sweden), [methyl-3H] thymidine 5'-triphosphate (dTTp) (Amersherdan, Tokyo, Japan), Adriamycin (Sigma Chemical Co., St. Louis, USA), Aquasol-2 (NEN Research Products, Boston, USA). HIV-1PR: As in reference [5].

\section{Plant material}

The bark, leaves and fruits of Grevillea robusta A.Cunn were collected from Assiut University garden on March 2003, and the plant was kindly identified by Prof. Dr. Ibrahim Hassan, Department of Horticulture, Faculty of Agriculture, Assiut University.

\section{Materials for phytochemical study}

$1 \mathrm{~kg}$ of the air-dried bark of Grevillea robusta A. Cunn was powdered and extracted with methanol by maceration for 48 hours. This process was repeated for three successive times and the combined alcoholic extract was concentrated under reduced pressure till afforded a syrupy dark residue $(100 \mathrm{~g})$.

\section{Fractionation and isolation}

The dried alcohol extract $(70 \mathrm{~g})$ was mixed with water and partitioned between n-hexane (1Lx3), $\mathrm{CHCl}_{3}$ (1Lx3), EtOAc (1Lx3) and n-butanol (1Lx3). The combined extract of each solvent was evaporated to dryness under vacuum to give hexane $(5 \mathrm{~g})$, $\mathrm{CHCl}_{3}(20 \mathrm{~g})$, EtOAc $(13 \mathrm{~g})$ and $\mathrm{n}$ butanol (25 g).

Ten grams of the dried chloroform-soluble fraction was fractionated over silica gel column chromatography (400 g) using gradient elution with $\mathrm{CHCl}_{3}$-EtOAc 
mixture as a solvent system. Fractions $(100 \mathrm{ml}$, each) were collected and monitored with TLC, similar fractions were combined. Fraction C-1 $(50 \mathrm{mg})$ eluted with $\mathrm{CHCl}_{3}$, where an orange crystals was obtained on repeated crystallysation from $\mathrm{CHCl}_{3}$ (compound 1, $20 \mathrm{mg}$ ). Fraction C-2 (400 mg) eluted with $\mathrm{CHCl}_{3}$-EtOAc (95:5) upon repeated crystallization from $\mathrm{CHCl}_{3}$, afforded $\beta$-sitosterol (compound 2, $300 \mathrm{mg}$ ). Fraction C-3 $\left(200 \mathrm{mg}\right.$ ) eluted with $\mathrm{CHCl}_{3}-\mathrm{EtOAc}$ (9:1) when subjected to silica gel column chromatography using $\mathrm{CHCl}_{3}-\mathrm{MeOH}$ (9:1) gave compound 3 (30 mg). Fraction C-4 (100 mg, $\mathrm{CHCl}_{3}$-EtOAc, (85:15) when subjected to sephadex LH-20 column chromatography afforded robustol ${ }^{5 \& 6}$ (compound 4, $20 \mathrm{mg}$ ) and other spots. These spots (minors) which attained orange colour after spraying with $\mathrm{H}_{2} \mathrm{SO}_{4}(10 \%)$, have the same $\mathrm{R}_{\mathrm{f}}$ value as polyalkyl phenols previously isolated from the leaves. ${ }^{5 \& 6}$ Fraction C-5 eluted with $\mathrm{CHCl}_{3}$-EtOAc (8:2) afforded $\beta$-sitosterol glucoside (compound 5, $100 \mathrm{mg}$ ) upon rechromatography on silica gel column using benzene-acetone mixture in a gradient manner.

Part of the dried n-butanol-soluble fraction $(15 \mathrm{~g})$ was subjected to a column of Diaion-HP-20 and eluted with water, $50 \% \mathrm{MeOH}, 100 \%$ $\mathrm{MeOH}$ and acetone respectively. The $50 \% \mathrm{MeOH}$ fraction $(7 \mathrm{~g})$ was chromatographed on silica gel using $\mathrm{CHCl}_{3}$-EtOAc gradient as a solvent system to give two groups of fractions. Fraction B-1 (100 mg) was eluted with $\mathrm{CHCl}_{3}$-EtOAc (8:2) subjected to LiChroprep RP-18 using $\mathrm{MeOH} 50 \%$, to afford compound 6 $(20 \mathrm{mg})$. Fraction B-2 (900 mg) was eluted with $\mathrm{CHCl}_{3}-\mathrm{EtOAc}(2: 8)$ and chromatographed on silica gel column using $\mathrm{CHCl}_{3}-\mathrm{MeOH}$ gradient as eluent to give three sub-fractions $(\mathrm{F}$ B-2-1, F B-2-2 and F B-2-3). F B-2-1 $\left[\mathrm{CHCl}_{3}-\mathrm{MeOH}(85: 15), 100 \mathrm{mg}\right]$ was subjected to sephadex column chromatography using $\mathrm{MeOH}$, followed by silica gel column chromatography using $\mathrm{CHCl}_{3}-\mathrm{MeOH}$ (4:1) to give compound 7 (15 mg). F B-2-2 $\left[\mathrm{CHCl}_{3}-\mathrm{MeOH} \quad(85: 15), 500\right.$ $\mathrm{mg}$ ] was subjected to sephadex column chromatography using $\mathrm{MeOH}$, followed by silica gel column chromatography using benzene$\mathrm{MeOH}$ (3:1) to afford compound $\mathbf{8}$ $(50 \mathrm{mg})$. F B-2-3 $\quad\left[\mathrm{CHCl}_{3}-\mathrm{MeOH}\right.$ $(8: 2), 300 \mathrm{mg}$ ] gave brown gummy residue which signed as compound 9 (70 mg).

TLC of the EtOAc-soluble fraction revealed the presence of many inseperable spots most of them are similar to those present in the leaves. ${ }^{5 \& 6}$ The isolation of these compounds is in progress now.

Compound 1 obtained as an orange crystals $(20 \mathrm{mg})$, m.p 248$250^{\circ}$. Molecular formula $\mathrm{C}_{8} \mathrm{H}_{8} \mathrm{O}_{4}$ from the EIMS m/z $168[\mathrm{M}]^{+}$. Other peaks at $\mathrm{m} / \mathrm{z}$ (\% rel.int.), 140 (2), 137 (2.3), 109 (3.6), 108 (1), 80 (3.3) and 28 (100). Possible fragmentation pattern was shown in (Fig. 2).

IR (KBr): 3050, 2945, 1690, 1640, $1452,1385,1338,1251,1215,1102$ and $869 \mathrm{~cm}^{-1} .{ }^{1} \mathrm{H}-\mathrm{NMR}\left(\mathrm{CDCl}_{3}, 500\right.$ 
$\mathrm{MHz}): \delta 3.8\left(6 \mathrm{H}, \mathrm{s}, \mathrm{OCH}_{3} \mathrm{X} 2\right)$ and $5.8(2 \mathrm{H}, \mathrm{s}, \mathrm{H}-3,5) .{ }^{13} \mathrm{C}-\mathrm{NMR}\left(\mathrm{CDCl}_{3}\right.$, $125 \mathrm{MHz}): \delta 56.5\left(\mathrm{OCH}_{3} \mathrm{X} 2\right), 107.5$ (C-3,5), 157.4 (C-2,6), 176.9 (C-1) and $186.9(\mathrm{C}-4)$.

Compound 2 obtained as white needle crystals (methanol), m.p 135$137^{\circ}$. IR (KBr): $3440,3050,1636$ and $1075 \mathrm{~cm}^{-1}$. It gave positive Libermann-Burchards test.

Compound 3 obtained as yellowish powder. ${ }^{1} \mathrm{H}-\mathrm{NMR}\left(\mathrm{CD}_{3} \mathrm{OD}, 500\right.$ $\mathrm{MHz}): \delta 6.9(2 \mathrm{H}, d, \mathrm{~J}=8.6 \mathrm{~Hz}, \mathrm{H}-$ 2,6), $6.7(2 \mathrm{H}, d, \mathrm{~J}=8.6 \mathrm{~Hz}, \mathrm{H}-3,5)$, 4.6. $(1 \mathrm{H}, m, \mathrm{H}-7), 0.9(3 \mathrm{H}, d, \mathrm{~J}=6.8$ $\mathrm{Hz}, \mathrm{CH}_{3}$ ), $\mathrm{OCH}_{3}$ (obscured under solvent peak). ${ }^{13} \mathrm{C}-\mathrm{NMR}$ ( $\mathrm{CD}_{3} \mathrm{OD}$, $125 \mathrm{MHz}$ ) (Table 1).

Compound 4 obtained as white needle crystals, m.p 143-144\% ${ }^{\circ}$ IR (KBr): 3440, 1615, 1228, 1201 and $1135 \mathrm{~cm}^{-1}$.

Compound 5 obtained as white needle crystals, m.p 270-280'. IR (KBr): 3415, 2960, 1636 and 1075 $\mathrm{cm}^{-1}$. It gave positive LibermannBurchards test.

Compound 6 obtained as white needle crystals, m.p 199-200 ${ }^{\circ}{ }^{1} \mathrm{H}-$ NMR $\left(\mathrm{CD}_{3} \mathrm{OD}, 500 \mathrm{MHz}\right) \delta 6.9(2 \mathrm{H}$, $d, \mathrm{~J}=9.5 \mathrm{~Hz}, \mathrm{H}-2,6), 6.6(2 \mathrm{H}, d, \mathrm{~J}=9.5$ $\mathrm{Hz}, \mathrm{H}-3,5), 4.7\left(1 \mathrm{H}, d, \mathrm{~J}=8 \mathrm{~Hz}, \mathrm{H}-1^{\prime}\right.$ glc). The other sugar protons appear at $\delta 3.3-4.4$.

Compound (7) obtained as brownish residue. ${ }^{1} \mathrm{H}-\mathrm{NMR}\left(\mathrm{CD}_{3} \mathrm{OD}\right.$, $500 \mathrm{MHz}): \delta 6.9(2 \mathrm{H}, d, \mathrm{~J}=8.7 \mathrm{~Hz}$, $\mathrm{H}-2,6), 6.6(2 \mathrm{H}, d, \mathrm{~J}=8.7 \mathrm{~Hz}, 3,5)$, $5.4(1 \mathrm{H}, d, \mathrm{~J}=1.2 \mathrm{~Hz}, \mathrm{H}-1 "$ apiose $)$, $4.7\left(1 \mathrm{H}, d, \mathrm{~J}=8.2 \mathrm{~Hz}, \mathrm{H}-1^{\prime}\right.$ glc $), 3.98$ $(1 \mathrm{H}, d, \mathrm{~J}=9.5 \mathrm{~Hz}, \mathrm{H}-4 " \mathrm{a}$ apiose $), 3.70$ $(1 \mathrm{H}, d, \mathrm{~J}=9.5 \mathrm{~Hz}, \mathrm{H}-4 " \mathrm{~b}$ apiose $)$. The other sugar protons appear at $\delta 3.3$ 4.5. ${ }^{13} \mathrm{C}-\mathrm{NMR}\left(\mathrm{CD}_{3} \mathrm{OD}, 75 \mathrm{MHz}\right)$ (Table 1).

Compound 8 obtained as brownish residue. ${ }^{1} \mathrm{H}-\mathrm{NMR}\left(\mathrm{CD}_{3} \mathrm{OD}, 500\right.$ $\mathrm{MHz}): \delta 6.9(2 \mathrm{H}, d, \mathrm{~J}=8.7 \mathrm{~Hz}, \mathrm{H}-$ $3,5), 6.6(2 \mathrm{H}, d, \mathrm{~J}=8.7 \mathrm{~Hz}, \mathrm{H}-2,6)$, $5.4(1 \mathrm{H}, s, \mathrm{H}-1 "$ apiose $), 4.5(1 \mathrm{H}, d$, $\mathrm{J}=7.2 \mathrm{~Hz}, \mathrm{H}-1^{\prime}$ glc. $), 4.2(2 \mathrm{H}, m, \mathrm{H}-$ 8), $3.3(2 \mathrm{H}, m, \mathrm{H}-7)$. The other sugar protons appear at $\delta 3.3-4.4{ }^{13} \mathrm{C}-\mathrm{NMR}$ $\left(\mathrm{CD}_{3} \mathrm{OD}, 125 \mathrm{MHz}\right)$ (Table 1).

Compound 9 obtained as brownish yellow residue, ${ }^{1} \mathrm{H}-\mathrm{NMR}$ $\left(\mathrm{CD}_{3} \mathrm{OD}, 500 \mathrm{MHz}\right) \delta 8.1(1 \mathrm{H}, d, \mathrm{~J}=$ $16.8 \mathrm{~Hz}, \mathrm{H}-7), 7.1(2 \mathrm{H}, d, \mathrm{~J}=9.2 \mathrm{~Hz}$, $\mathrm{H}-2,6), 6.6(2 \mathrm{H}, d, \mathrm{~J}=9.2 \mathrm{~Hz}, \mathrm{H}-3,5)$, $6.4(1 \mathrm{H}, d, \mathrm{~J}=16.8 \mathrm{~Hz}, \mathrm{H}-8), 5.4(1 \mathrm{H}$, $\mathrm{s}, \mathrm{H}-1 "$ apiose), $4.64(1 \mathrm{H}, d, \mathrm{~J}=7.5$ $\mathrm{Hz}, \mathrm{H}-1$ ' glc.), $4.52(1 \mathrm{H}, \mathrm{d}, \mathrm{J}=7.8 \mathrm{~Hz}$, $\mathrm{H}-1$ "' glc. $), 4.05(1 \mathrm{H}, d, \mathrm{~J}=9.5 \mathrm{~Hz}, \mathrm{H}-$ 4"a apiose), $3.76(1 \mathrm{H}, d, \mathrm{~J}=9.5 \mathrm{~Hz}$, H-4"b apiose). The other sugar protons appear at $\delta 3.3-4.5{ }^{13} \mathrm{C}-\mathrm{NMR}$ $\left(\mathrm{CD}_{3} \mathrm{OD}, 125 \mathrm{MHz}\right)$ (Table 1).

\section{Acid hydrolysis}

Compound 7 was subjected to partial acid hydrolysis using 5\% methanolic $\mathrm{HCl}$ for 3 hours, small samples were withdrawn at $10 \mathrm{~min}$. intervals from the reaction mixture and spotted on TLC and PC alongside with authentic samples.

For complete acid hydrolysis five $\mathrm{mg}$ of each glycoside was refluxed with $2 \mathrm{~N}$ methanolic $\mathrm{HCl}$ for 3 hours. The reaction mixture was diluted with water and the aglycone was extracted with ether. The aqueous layer was neutralized with barium carbonate, filtered and evaporated under 
vaccum. The residue was dissolved in $\mathrm{MeOH}$ for identification.

\section{Preliminary biological screening Preparation of the extract for anti- inflammatory study}

Twenty grams of each of the powdered leaves and bark were separately extracted with $90 \% \mathrm{MeOH}$ till exhaustion. The alcohol extract of each organ was separately evaporated under reduced pressure yielding $3 \mathrm{~g}$ and $2 \mathrm{~g}$ respectively. The residue of both leaves and bark were separately dissolved in $2 \%$ Tween-80 to obtain 400 and $200 \mathrm{mg} / \mathrm{kg}$ concentration of each.

The anti-inflammatory activity of the alcoholic extracts of Grevillea robusta A. Cunn. bark and leaves was performed. Six groups, each of four male albino rats (150-170 g) were used. At the beginning of the experiment edema was induced in rats by backpaw sub-planter injection of $0.4 \mathrm{ml}$ of $1 \%$ carrageenan suspension ${ }^{8}$ by injection into right paw. The volume displacement was measured in $\mathrm{mm}$ by using Varinier calibor.

The plant extracts, indomethacin $(8 \mathrm{mg} / \mathrm{kg}$, as a positive control) and $2 \%$ tween-80 (in saline, as a negative control) were taking orally 30 minutes before testing of paw swelling. Paw volumes were assessed just after carrageenan injection and 30,60, 120, 180 and $240 \mathrm{~min}$. afterwards. The inflammatory response is represented as the percentage of paw edema inhibition, calculated for each group at each time point, using the following equation:
$\%$ Inhibition $=$

$\frac{(V t-V o) \text { control }-(V t-V o) \text { treated } x 100}{(V t-V o) \text { control }}$

Where $\mathrm{Vt}$ is the average volume at each time point and $V_{o}$ is the average volume just after carrageenan injection. The results are illustrated in Tables (4 and 5).

\section{Preparation of the extract for HIV-} 1PR and RT inhibitory test ${ }^{5}$

$50 \mathrm{~g}$ of each of the powdered fruits and bark was separately extracted with water and methanol under reflux for $3 \mathrm{hr}$. The extracts were filtered and evaporated under reduced pressure. The dried extracts were separately prepared to give solution of $2 \mathrm{mg} / \mathrm{ml}$. The sample solution was used in the reaction mixture for determination of HIV, HIV-1PR and HIV-RT inhibitory activity.

The reaction mixture for HIV-1PR inhibitory activity

- PR enzyme: dissolved in $(50 \mathrm{mM}$ NaOAc, pH: 5.02, $1 \mathrm{mM}$ EDTA.2Na, $2 \mathrm{mM}$ mercaptoethanol): glycerol [75:25].

- Substrate: peptide dissolved in 50 $\mathrm{mM} \mathrm{NaOAc}$ (pH: 5.02).

- Buffer solution: $50 \mathrm{mM} \mathrm{NaOAc}$ (pH: 5.02).

Method of assay of HIV-1PR inhibitory activity

$1 \mu \mathrm{l}$ of buffer was placed in a tube and centrifuge. $1 \mu \mathrm{l}$ of the substrate and $1 \mu l$ of the sample were transferred in the same tube (centrifuge and mix after each addition). $2 \mu l$ of the enzyme was added on the wall of 
the tube (without mixing), until finishing the addition of the enzyme to all tubes, centrifuge, mix and recentrifuge. All the tubes were incubated at $37^{\circ}$ for 1-2 hours. The reaction was stopped by heating the tubes in water bath at $90^{\circ}$ for $1 \mathrm{~min}$. $35 \mu \mathrm{l}$ of distilled water was added, centrifuge, mix and centrifuge again, transfer $40 \mu \mathrm{l}$ of the reaction mixture to HPLC glass tubes and put them in HPLC for analysis as in reference 5 and references cited herein.

The reaction mixture for HIV-RT inhibitory activity

$50 \mathrm{mM}$ Tris- $\mathrm{HCl}$ (pH 8.3), $30 \mathrm{mM}$ $\mathrm{NaCl}, 10 \mathrm{mM} \mathrm{MgCl} 2,5 \mathrm{mM}$ DTT, 5 $\mu \mathrm{g} / \mathrm{ml}$ template-primer $(\mathrm{rA})_{\mathrm{n}} \quad \mathrm{P}$ (dT)12-18. 0.1 mM methyl-[ $\left[{ }^{3} \mathrm{H}\right] \mathrm{dTTP}$ (18.5 MBq/ml) and $0.5 \mathrm{U}$ of RT enzyme in a final volume of $20 \mu \mathrm{l}$.

\section{Method of assay of HIV-1RT inhibitory activity ${ }^{5}$}

The reaction mixture was prepared (except the addition of the enzyme). The plant extract was dissolved in DMSO and $1 \mu$ l of it was added to the reaction mixture, which was incubated for $30 \mathrm{~min}$ at $37^{\circ}$. The reaction was stopped by immersion in ice and addition of 0.2 M EDTA. 10 $\mu l$ of the reaction mixture was applied to DEAE-cellulose discs. Wash the discs with $5 \% \quad \mathrm{Na}_{2} \mathrm{HPO}_{4}(5 \times 3 \quad \mathrm{ml})$, distilled water $(2 \times 3 \mathrm{ml}), 99 \%$ ethanol $(2 \times 3 \mathrm{ml})$ and finally with ether $(1 \times 3$ $\mathrm{ml})$.

\footnotetext{
\% inhibition was calculated through the equation $\%$ inhibition $=$

[1- (dpm test/dpm control)] X 100 $\mathrm{dpm}=$ disentigretion per $\min$
}

Control assay is performed by adding DMSO (final conc. 5\%) containing no sample. $0.5 \mathrm{mM}$ Adriamycin is used as a positive control, which inhibited the enzyme activity by $99.0 \%$.

Direct HIV-1 inhibitory activity reagent and method of screening as mentioned in literatures ${ }^{5 \& 9}$

The results for HIV-1, HIV-1 PR and RT inhibitory activities were represented in Tables (2 and 3).

Table 1: ${ }^{13} \mathrm{C}-\mathrm{NMR}$ data of compounds 3,8,9 $\left(\mathrm{CD}_{3} \mathrm{OD}, 125 \mathrm{MHz}\right)$ and $7\left(\mathrm{CD}_{3} \mathrm{OD}, 75 \mathrm{MHz}\right)$.

\begin{tabular}{|c|c|c|c|c|}
\hline C & 3 & 7 & 8 & 9 \\
\hline 1 & 154.2 & 132.40 & 131.0 & 125.0 \\
\hline 2,6 & 117.0 & 119.42 & 132.1 & 135.3 \\
\hline 3,5 & 128.1 & 116.69 & 117.7 & 117.1 \\
\hline 4 & 133.0 & 152.34 & 151.1 & 152.7 \\
\hline 7 & 70.4 & & 37.8 & 140.5 \\
\hline 8 & 14.2 & & 71.6 & 115.0 \\
\hline $\mathrm{C}=\mathrm{O}$ & & & & 167.6 \\
\hline \multicolumn{5}{|l|}{ Glc-1 } \\
\hline $1^{\prime}$ & & 102.24 & 100.9 & 102.4 \\
\hline $2^{\prime}$ & & 77.94 & 77.3 & 74.09 \\
\hline $3^{\prime}$ & & 78.12 & 76.7 & 77.3 \\
\hline $4^{\prime}$ & & 71.52 & 70.1 & 70.1 \\
\hline $5^{\prime}$ & & 78.77 & 77.3 & 76.6 \\
\hline $6^{\prime}$ & & 62.56 & 61.1 & 63.4 \\
\hline \multicolumn{5}{|l|}{ Apiose } \\
\hline 1" & & 110.76 & 109.0 & 109.4 \\
\hline $2 "$ & & 78.64 & 76.6 & 76.5 \\
\hline 3" & & 80.74 & 79.5 & 79.4 \\
\hline 4" & & 75.43 & 74.1 & 73.6 \\
\hline $5 "$ & & 66.70 & 64.7 & 64.7 \\
\hline \multicolumn{5}{|l|}{ Glc-2 } \\
\hline $1 " '$ & & & & 100.8 \\
\hline $2^{\prime \prime \prime}$ & & & & 74.03 \\
\hline $3 " '$ & & & & 76.73 \\
\hline $4 " '$ & & & & 70.2 \\
\hline $5 " '$ & & & & 76.75 \\
\hline 6"' & & & & 61.1 \\
\hline $\mathrm{OCH}_{3}$ & 59.5 & & & \\
\hline
\end{tabular}


Table 2: HIV-1 RT inhibitory activity of different fractions of the methanol extract of Grevillea robusta A. Cunn. bark and fruit.

\begin{tabular}{|c|c|c|c|}
\hline \multirow{3}{*}{ Fraction } & \multicolumn{3}{|c|}{$\%$ inhibition } \\
\hline & \multicolumn{2}{|c|}{ Bark } & Fruit \\
\hline & $(100 \mu \mathrm{g} / \mathrm{ml})$ & $(200 \mu \mathrm{g} / \mathrm{ml})$ & $(200 \mu \mathrm{g} / \mathrm{ml})$ \\
\hline $\mathrm{CHCl}_{3}$ & $\mathrm{NI}$ & $\mathrm{NI}$ & $6.8 \pm 2.3$ \\
\hline EtOAc & $\mathrm{NI}$ & $86.1 \pm 6.9$ & $22.7 \pm 8.2$ \\
\hline $\mathrm{BuOH}$ & $\mathrm{NI}$ & $47.7 \pm 5.8$ & NT \\
\hline
\end{tabular}

$\mathrm{NI}=$ no inhibition

NT $=$ not tested

Table 3: HIV-1 PR inhibitory activity and anti-HIV activity of methanol and aqueous extracts of Grevillea robusta A. Cunn. bark.

\begin{tabular}{|c|l|c|c|c||}
\hline \multirow{2}{*}{ Extract } & \multicolumn{2}{|c|}{ \% inhibition } & \multicolumn{2}{c||}{ Anti-HIV } \\
\cline { 2 - 5 } & $200 \mu \mathrm{g} / \mathrm{ml}$ & $100 \mu \mathrm{g} / \mathrm{ml}$ & IC & CC \\
\hline $\mathrm{MeOH}$ & $47.3 \pm 1.2$ & $10.5 \pm 1.2$ & & \\
\hline $\mathrm{H}_{2} \mathrm{O}$ & $46.7 \pm 7.6$ & Not tested & 2500 & $\geq 1000$ \\
\hline
\end{tabular}

$\mathrm{IC}=$ the minimum concentration for complete inhibition of HIV-1 induced CEP in MT-4 cells by microscopic observation.

$\mathrm{CC}=$ the minimum concentration for the appearance of MT- 4 cell toxicity by microscopic observation.

Table 4: Anti-inflammatory effect of the alcoholic extracts of G. robusta A.Cunn bark and leaves.

\begin{tabular}{|c|c|c|c|c|c|c|}
\hline \multirow[t]{2}{*}{ Group } & \multicolumn{6}{|c|}{ Thickness of the right paw $(\mathrm{mm})($ mean \pm S.E. $)$} \\
\hline & zero & $1 / 2 \mathrm{hr}$ & $1 \mathrm{hr}$ & $2 \mathrm{hr}$ & $3 \mathrm{hr}$ & $4 \mathrm{hr}$ \\
\hline -ve control & $7.5 \pm 0.016$ & $7.5 \pm 0.03$ & $7.5 \pm 0.016$ & $8.2 \pm 0.04$ & $8.4 \pm 0.016$ & $8.5 \pm 0.016$ \\
\hline Indomethacin & $7.0 \pm 0.01$ & $6.5 \pm 0.012$ & $5.8 \pm 0.016^{* *}$ & $5.3 \pm 0.028 * *$ & $5.3 \pm 0.033 * *$ & $4.6 \pm 0.033^{* * *}$ \\
\hline Bark & \multirow[b]{2}{*}{$7.0 \pm 0.028$} & \multirow[b]{2}{*}{$6.6 \pm 0.016$} & \multirow[b]{2}{*}{$6.5 \pm 0.013$} & \multirow[b]{2}{*}{$6.5 \pm 0.028$} & \multirow[b]{2}{*}{$5.7 \pm 0.028 * *$} & \multirow[b]{2}{*}{$6.6 \pm 0.033$} \\
\hline $200 \mathrm{mg} / \mathrm{kg}$ & & & & & & \\
\hline $400 \mathrm{mg} / \mathrm{kg}$ & $6.8 \pm 0.016$ & $6.3 \pm 0.033$ & $6.3 \pm 0.025^{*}$ & $6.3 \pm 0.016^{*}$ & $5.6 \pm 0.033 * *$ & $5.6 \pm 0.014 * *$ \\
\hline Leaves & \multirow[b]{2}{*}{$6.8 \pm 0.016$} & \multirow[b]{2}{*}{$6.8 \pm 0.017$} & \multirow[b]{2}{*}{$6.3 \pm 0.016^{*}$} & \multirow[b]{2}{*}{$5.6 \pm 0.016^{* *}$} & \multirow[b]{2}{*}{$5.5 \pm 0.018^{* *}$} & \multirow[b]{2}{*}{$6.0 \pm 0.017 * *$} \\
\hline $200 \mathrm{mg} / \mathrm{kg}$ & & & & & & \\
\hline $400 \mathrm{mg} / \mathrm{kg}$ & $6.2 \pm 0.016$ & $6.1 \pm 0.017 *$ & $6.1 \pm 0.017 *$ & $5.5 \pm 0.019 * *$ & $5.56 \pm 0.014 * *$ & $5.5 \pm 0.016^{* *}$ \\
\hline
\end{tabular}

T-test $(* \mathrm{p}<0.05, * * \mathrm{p}<0.01)$ 
Table 5: \% of edema inhibition of the alcoholic extracts of G. robusta A. Cunn bark and leaves.

\begin{tabular}{|c|c|c|c|c|c|c|}
\hline \multirow[t]{2}{*}{ Group } & \multicolumn{6}{|c|}{$\%$ of inhibition } \\
\hline & zero & $1 / 2 \mathrm{hr}$ & $1 \mathrm{hr}$ & $2 \mathrm{hr}$ & $3 \mathrm{hr}$ & $4 \mathrm{hr}$ \\
\hline -ve control & - & - & - & - & - & - \\
\hline Indomethacin & 7 & 13 & 23 & 35 & 37 & 46 \\
\hline Bark & & & & & & \\
\hline $200 \mathrm{mg} / \mathrm{kg}$ & 7 & 12 & 13 & 21 & 32 & 22 \\
\hline $400 \mathrm{mg} / \mathrm{kg}$ & 9 & 16 & 16 & 23 & 33 & 33 \\
\hline Leaves & & & & & & \\
\hline $200 \mathrm{mg} / \mathrm{kg}$ & 9 & 9 & 16 & 32 & 35 & 29 \\
\hline $400 \mathrm{mg} / \mathrm{kg}$ & 17 & 17 & 19 & 33 & 35 & 35 \\
\hline
\end{tabular}

\section{RESULTS AND DISCUSSION}

The dried bark of Grevillea robusta A.Cunn was extracted with $\mathrm{MeOH}$, and the extract was fractionated with n-hexane, $\mathrm{CHCl}_{3}$, EtOAc and n-butanol. From the $\mathrm{CHCl}_{3}$-soluble fraction five compounds were isolated using different types of chromatography. The n-butanol-soluble fraction was applied on a column of Diaion-HP 20 and eluted with water, $50 \% \mathrm{MeOH}$, $100 \% \mathrm{MeOH}$ and acetone. From the $50 \% \mathrm{MeOH}$, four compounds were isolated.

Compound 1 was obtained as an orange crystals. Its molecular formula was established as $\mathrm{C}_{8} \mathrm{H}_{8} \mathrm{O}_{4}$ on the basis of EIMS which showed molecular ion peak $\left[\mathrm{M}^{+}\right]$at $\mathrm{m} / \mathrm{z} 168$. ${ }^{13} \mathrm{C}-\mathrm{NMR}$ data of compound $\mathbf{1}$ showed five signals equivalent to eight carbon atoms including four quaternary at $\delta_{\mathrm{C}} 186.9,157.4(2 \mathrm{C})$ and 176.9, two methine carbon atoms at $\delta_{\mathrm{C}} 107.5$ (2C) and two methoxy at $\delta_{\mathrm{C}} 56.5$ (2C). The ${ }^{1} \mathrm{H}$-NMR spectral data, showed only two signals at $\delta_{\mathrm{H}}$ $5.8(2 \mathrm{H}, \mathrm{s}, \mathrm{H}-3,5)$, and at $\delta_{\mathrm{H}} 3.4(6 \mathrm{H}$, $\mathrm{s}, \mathrm{OCH}_{3} \mathrm{X} 2$ ).

The above mentioned data indicated the presence of 1,4 benzoquinone derivatives where the signal at $\delta_{\mathrm{C}} 186.9$ is characterized for the carbonyl carbon at C-4, while the signal at $\delta_{\mathrm{C}} 176.9$ corresponding to another carbonyl carbon at C-1. The possible fragmentation pattern of compound 1 (Fig. 2) was in a good agreement with the proposed structure. From the above mentioned data, the compound was identified as 2,6-dimethoxy-1,4-benzoquinone.

This compound was reported for the first time from the family Proteaceae, and it is previously isolated from the wood of Kielmeyera rupestris A.P.Duarte ${ }^{10}$ and from the root of Heliicteres angustifolia L. ${ }^{11}$ 
1,4 benzoquinone is harmfull to skin and eyes, causing dermatitis and conjunctivitis. It is used as an oxidizing agent in photography and in manufacture of dyestuff. 2,6dimethoxy benzoquinone has been reported as an anticancer agent. ${ }^{12}$

Compound 2 was obtained as white needle crystals, and it was identified as $\beta$-sitosterol by direct comparison with authentic sample (m.m.p and co-chromatography).

Compound 3 was obtained as yellowish powder. The ${ }^{1} \mathrm{H}-\mathrm{NMR}$ spectrum of $\mathbf{3}$ exhibited the characteristic signals belong to the 1,4- disubstituted benzene ring as an $\mathrm{AB}$ system at $\delta 6.9(2 \mathrm{H}, d, \mathrm{~J}=8.6$ $\mathrm{Hz}, \mathrm{H}-2,6), 6.7(2 \mathrm{H}, d, \mathrm{~J}=8.6 \mathrm{~Hz}, \mathrm{H}-$ $3,5)$, one methine proton at $\delta 4.6(1 \mathrm{H}$, $\mathrm{m})$ and one methyl group at $\delta 0.9$ $\left(3 \mathrm{H}, d, \mathrm{~J}=6.8 \mathrm{~Hz}, \mathrm{CH}_{3}\right)$. The ${ }^{13} \mathrm{C}-$ NMR spectral data showed signals for $\mathrm{AB}$-spin system at $\delta 128.1$ and 117.0, methine carbon at $\delta$ 70.4, methyl carbon at 14.2 and aromatic methoxy group at $\delta 59.5$. Usually the connection of benzene ring to oxygen atom results in a downfield shift of the connected carbon, ${ }^{6}$ in compound 3 one of the substituted carbons appears at $\delta 133.0$ indicating its connection to another carbon not to oxygen atom, while the second substituted carbon appear at $\delta 154.2$ indicating its connection to an oxygen atom. Comparing these data to that of anisol and $p$-cresol, ${ }^{13}$ compound $\mathbf{3}$ was suggested to has the structure showed in Fig. 1 and was supposed to be 4-(1-hydroxy ethyl) anisol.
Compound 4 was obtained as white needle crystals, The IR spectrum showed signals for hydroxy group at $3440 \mathrm{~cm}^{-1}$, aromatic ring at $1615 \mathrm{~cm}^{-1}$ and ether linkage at 1228 , 1201 and $1135 \mathrm{~cm}^{-1}$. It was identified as robustol by direct comparison with authentic sample (m.m.p and cochromatography).

Compound 5 was obtained as white needle crystals, and it was identified as $\beta$-sitosterol glucoside by direct comparison with authentic sample (m.m.p and cochromatography).

Compound 6 was isolated as white needle crystals. The ${ }^{1} \mathrm{H}-\mathrm{NMR}$ spectral data, showed signals at $\delta_{\mathrm{H}} 6.9$ $(2 \mathrm{H}, d, \mathrm{~J}=9.5 \mathrm{~Hz}, \mathrm{H}-2,6)$ and 6.6 $(2 \mathrm{H}, d, \mathrm{~J}=9.5 \mathrm{~Hz}, \mathrm{H}-3,5)$ suggesting the presence of aromatic protons as an AB-spin system. The presence of signal at $\delta_{\mathrm{H}} 4.7\left(1 \mathrm{H}, d, \mathrm{~J}=8 \mathrm{~Hz}, \mathrm{H}-1^{\prime}\right.$ glc) with the other signals at $\delta_{\mathrm{H}} 3.3$ 4.4 , indicating the glycosidic nature of this compound. The large $\mathrm{J}$ value of the anomeric proton indicating the $\beta$-configuration of the sugar. The ${ }^{1} \mathrm{H}$ NMR spectrum was similar to that of arbutin. ${ }^{5 \& 6}$ Acid hydrolysis of compound $\mathbf{6}$ afforded aglycone identified as hydroquinone (m.p $171^{\circ}$, co-chromatography, system 2) and one sugar identified as glucose (PC, system 3 ). The structure of compound 6 was confirmed by cochromatography with authentic sample of arbutin using system 1 . Therefore, compound $\mathbf{6}$ was presumed to be arbutin.

Compound 7 was isolated as brownish residue. The ${ }^{1} \mathrm{H}-\mathrm{NMR}$ 
spectral data were similar to those of arbutin $\delta_{\mathrm{H}} 6.9(2 \mathrm{H}, d, \mathrm{~J}=8.7 \mathrm{~Hz}, \mathrm{H}-$ 2,6), $6.6(2 \mathrm{H}, d, \mathrm{~J}=8.7 \mathrm{~Hz}, 3,5)$, with an additional anomeric proton at $\delta_{\mathrm{H}}$ $5.4(1 \mathrm{H}, d, \mathrm{~J}=1.2 \mathrm{~Hz}, \mathrm{H}-1 "$ apiose). ${ }^{13} \mathrm{C}-\mathrm{NMR}$ spectrum showed the presence of 15 carbon signals for 17 carbons, four of them were assigned for $p$-hydroquinone. The rest of the carbons were assigned to pentose (apiose) and hexose (glucose) sugars (Table 1). The attachement of apiose to glucose was deduced to be in C-2' from the downfield shift of C-2' $(\approx$ $3.5 \mathrm{ppm}$ ). Mild acid hydrolysis of 7 yielded a sugar identified as apiose (PC, system 3) and arbutin (cochromatography, system 1). Complete acid hydrolysis gave aglycone identified as hydroquinone (cochromatography, system 2) and two sugars identified as glucose and apiose (PC, system 3). Finally, comparing the chemical shift of anomeric proton of apiose with that reported for arbutin 2'-O- $\beta$ apiofuranoside and arbutin 6 '- $O-\beta$ apiofuranoside, ${ }^{14}$ the structure of compound 7 was elucidated to be 2 $\mathrm{O}-\beta$-apiofuranosyl arbutin. This is the first report for the isolation of this compound from family Proteaceae.

Compound 8 was obtained as brownish residue. The NMR data showed signals at $\delta \mathrm{c} 100.9$ with $\delta_{\mathrm{H}}$ 4.5 and $\delta \mathrm{c} 109.0$ with $\delta_{\mathrm{H}} 5.4$ corresponding to anomeric carbons and protons of $\beta$-glucopyranosyl and $\beta$-apiofuranosyl moieties respectively.

In the ${ }^{1} \mathrm{H}-\mathrm{NMR}$ spectra, the signals due to the two methylene protons displayed at $\delta 3.3$ and 4.2, besides, signals at $\delta 6.6$ and 6.9 (ABspin system, each $2 \mathrm{H}, d, \mathrm{~J}=8.7 \mathrm{~Hz}$, $\mathrm{H}-2,6$ and $\mathrm{H}-3,5)$ suggesting the presence of $p$-hydroxyphenethyl alcohol moiety.

The ${ }^{13} \mathrm{C}-\mathrm{NMR}$ spectral data showed signals for two methylenes at $\delta 37.8$ and 71.6 and $p$-hydroxyphenyl at $\delta 131.0,132.1,117.7$ and 151.1 confirmed the presence of $p$ hydroxyphenethyl alcohol moiety as aglycone part of this compound. The $\beta$-configuration of apiose was confirmed from the chemical shift of C-1" in ${ }^{13} \mathrm{C}$-NMR spectra. ${ }^{15}$

These data indicated the presence of salidroside ( $p$-hydroxy phenethyl$\beta$-glucopyranosyl) in addition to apiosyl moiety. The attachment of apiose to C-2' of glucose was determined by downfield shift $(\delta 2.2$ ppm) of C-2' of glucose (appeared at $\delta 77.3 \mathrm{ppm})$ when compared with salidroside. ${ }^{16}$

So, the structure of compound $\mathbf{8}$ was supposed to be 4-hydroxy phenethyl alcohol 8-O- $\beta$ apiofuranosyl $\quad\left(1 " \rightarrow 22^{\prime}\right) \quad-\beta$ glucopyranoside. This is the first report for the isolation of this compound from family Proteaceae.

Compound 9 was obtained as brownish yellow residue. The ${ }^{1} \mathrm{H}$ NMR spectrum of 9 exhibited the characteristic signals belong to the trans p-coumaroyl four aromatic protons as an $\mathrm{AB}$ system at $\delta 7.1$ $(2 \mathrm{H}, \mathrm{d}, \mathrm{J}=9.2 \mathrm{~Hz}, \mathrm{H}-2,6), 6.6(2 \mathrm{H}, d$, $\mathrm{J}=9.2 \mathrm{~Hz}, \mathrm{H}-3,5)$, and two olefinic protons signals at $\delta 8.1\left(1 \mathrm{H}_{2}, d, \mathrm{~J}=\right.$ $16.8 \mathrm{~Hz}, \mathrm{H}-7), 6.4(1 \mathrm{H}, \mathrm{d}, \mathrm{J}=16.8 \mathrm{~Hz}$, $\mathrm{H}-8)$ indicating the trans 
configuration of the $p$-coumaroyl moeity.

Additionally, the three anomeric proton resonances appeared at $\delta_{\mathrm{H}} 4.64$ $(1 \mathrm{H}, d, \mathrm{~J}=7.5, \mathrm{H}-1$ ' glc. $), 4.52(1 \mathrm{H}, d$, $\left.\mathrm{J}=7.8, \mathrm{H}-1{ }^{\prime \prime}\right)$ and $5.4(1 \mathrm{H}, s, \mathrm{H}-1 "$ apiose), indicating the triglycosidic structure. The ${ }^{13} \mathrm{C}-\mathrm{NMR}$ spectroscopic data confirmed the triglycosidic structure of $\mathbf{9}$ exhibiting three anomeric carbon resonances at $\delta c 109.4,102.4$ and 100.8. The connection of sugar moieties was proved to be as in Fig. 1, these results were supported by a mild and complete acid hydrolysis of 9 yielded two sugar moieties, and aglycone. The sugars were identified as glucose and apiose ( $\mathrm{PC}$, system 3) using authentic sugars and the aglycone identified as $p$-coumaric acid (cochromatography, system 2). The relatively large $J$ values of anomeric protons indicated $\beta$-configurations for both glucopy-ranosyl moieties. The proton and carbon chemical shifts due to the apiose unit indicated that, it has to be in the terminal position. ${ }^{15}$ The carbon resonances arising from the two glucose moieties revealed that one glucose unit was glycosylated at $\mathrm{C}-1^{\prime}\left(\delta_{\mathrm{C}} 102.4\right)$ and $\mathrm{C}-6^{\prime}\left(\delta_{\mathrm{C}} 63.4\right)$, while the second glucose unit at $\mathrm{C}-1$ "' $\left(\delta_{\mathrm{C}}\right.$ 100.8). The attachment of the second glucose unit to C-4 of $p$ coumaroyl moiety was supported by the slight upfield shift of C-4 $\left(\delta_{\mathrm{C}}\right.$ 152.7) and the down field shift of $\mathrm{C}$ $3,5\left(\delta_{\mathrm{C}} 117.1\right){ }^{6}$
The ${ }^{13} \mathrm{C}$ signals assigned to the aglycone moiety were almost the same as that reported for the trans $p$ coumaroyl moiety. ${ }^{6}$ The ${ }^{13} \mathrm{C}-\mathrm{NMR}$ shift of the anomeric carbon of the apiofuranosyl unit at $(\delta c$ 109.4) indicating $\tilde{\beta}$ configuration. ${ }^{15}$

HMBC experiment permitted the determination of all the relevant interfragmental connec-tivities. Thus cross peaks were observed between carbonyl carbon $\left(\delta_{\mathrm{C}} 167.6\right)$ of the $p$ coumaroyl moiety and the $\mathrm{H}-1^{\prime}\left(\delta_{\mathrm{H}}\right.$ 4.57 ) of the first glucose unit, C-4 of $p$-coumaroyl moiety $\left(\delta_{\mathrm{C}} 152.7\right)$ and the H-1"' $\left(\delta_{\mathrm{H}} 4.64\right)$ of the second glucose unit, C-6 $\left(\delta_{\mathrm{C}} 63.4\right)$ of the first glucose unit and $\mathrm{H}-1$ " of the apiose $\left(\delta_{\mathrm{H}}\right.$ 5.4). Finally, alkaline hydrolysis of compound 9 yielded two sugars identified as glucose and apiose. Based on these results, the structure of compound 9 was established as 4 $O$-p-coumaroyl $\{\beta$-glucopyranoside $\}$ 8-O- $\beta$-apiofuranosyl- $\left.\left(1^{\prime \prime} \rightarrow 6^{\prime}\right)\right\}-O-\beta$ glu-copyranosyl. This is the first report for the isolation of this compound from family Proteaceae.

The isolated compounds having a phenolic nucleus were previously isolated from many plants belonging to family Proteaceae, from the taxonomic point of view it is interesting to make a scheme for the possible biogenetic pathway of the isolated compounds as illustrated in Fig. 3. 
<smiles>COC1=CC(=O)C=C(OC)C1=O</smiles>

Compound 1

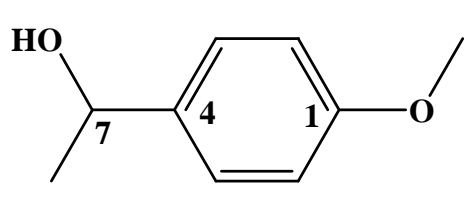

Compound 3

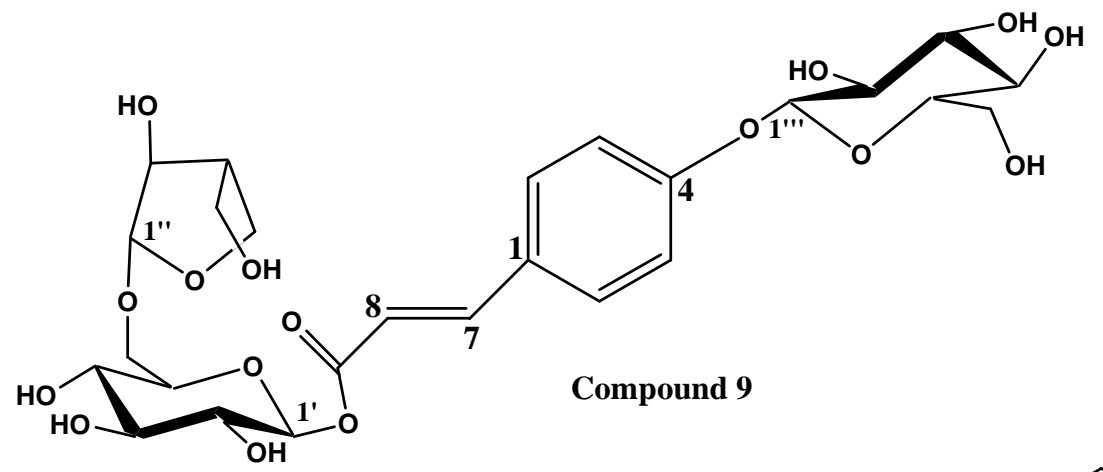

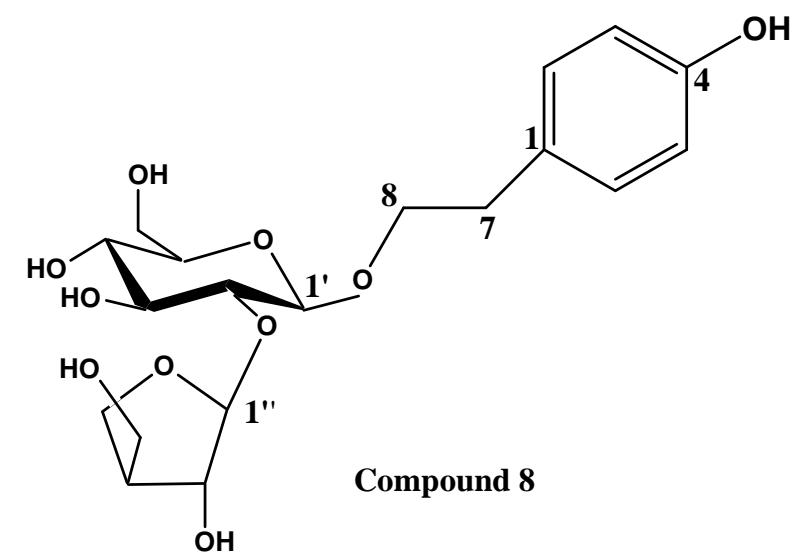

Compound 6, $R=$ Glucose

Compound 7, $R=$ Apiose (1"'-2')-glucose

Fig. 1: List of the isolated phenolic compounds from Grevillea robusta A. Cunn bark. 


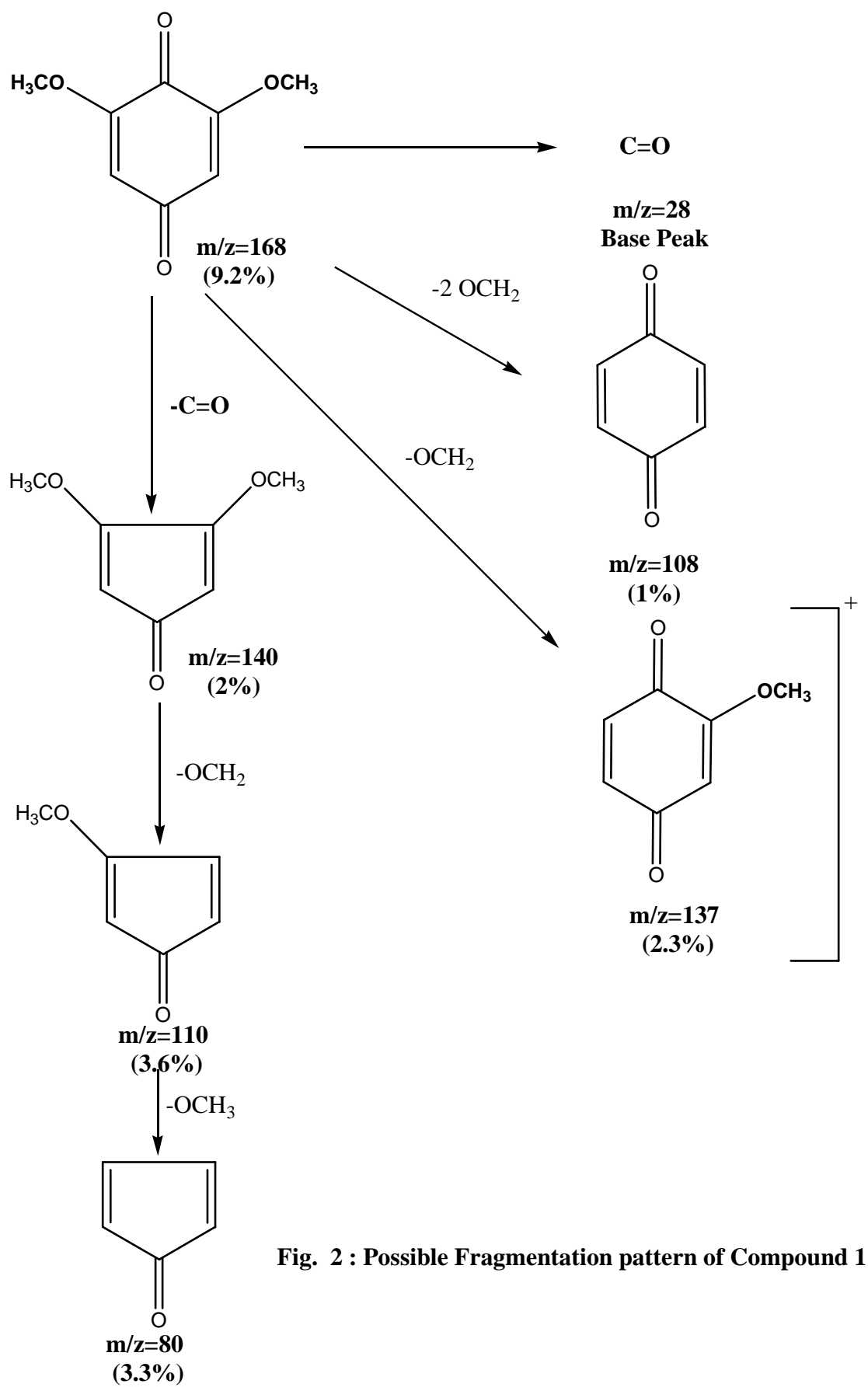



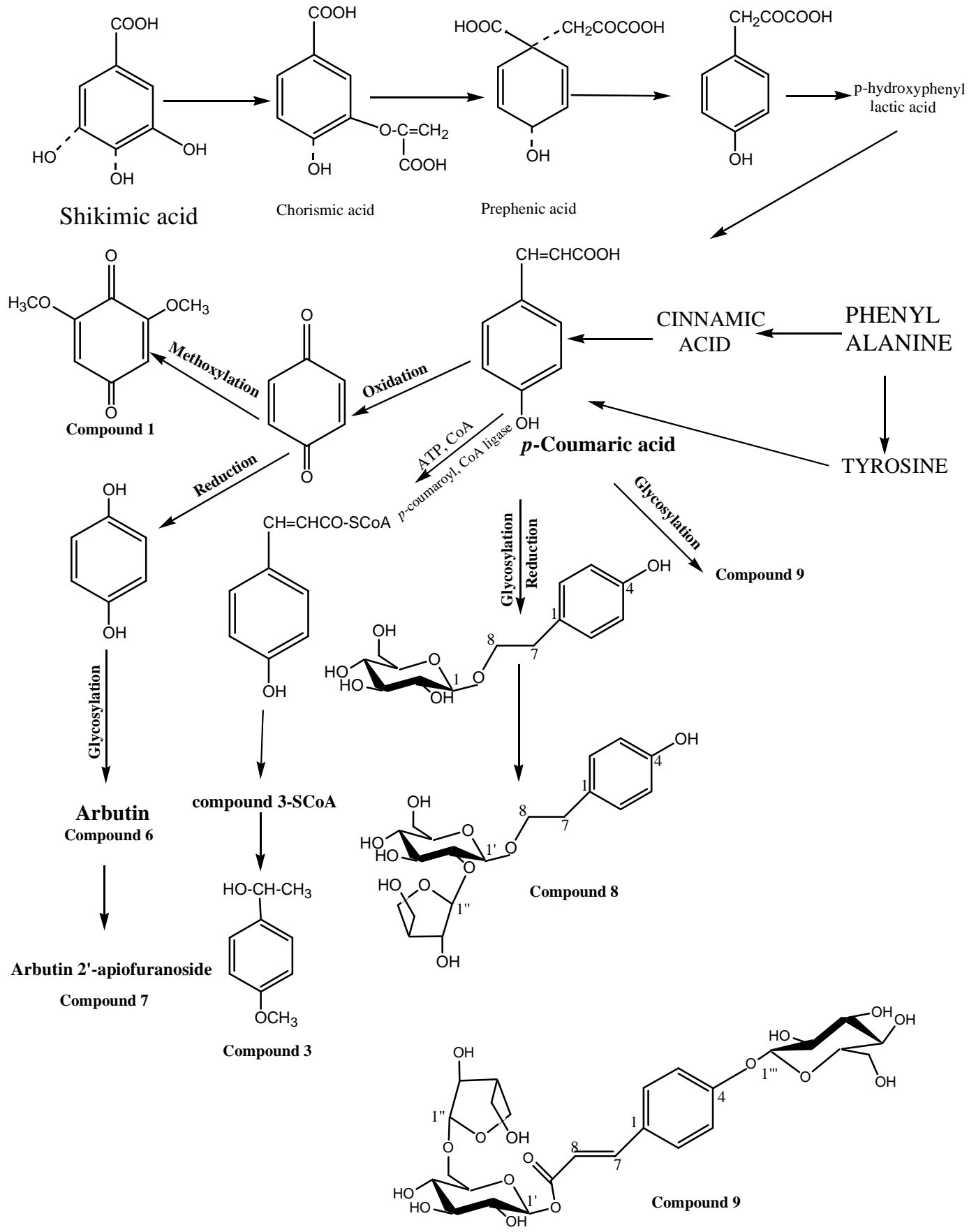

Fig. 3: Possible biogenitic pathway of the isolated compounds. 


\section{Antiinflammatory effect}

Effects of Grevillea robusta A.Cunn alcoholic extracts of the leaves and bark and indomethacin on carrageenan induced inflammation were represented as time course of edema (Table 4). At $400 \mathrm{mg} / \mathrm{kg}$ dose level, results indicated that the tested extracts caused a marked decrease in edema when compared to control group. The anti-inflammatory activity of the alcoholic extract of the bark $(400 \mathrm{mg} / \mathrm{kg}$ ) reach its maximum after 2 hours, and be approximately similar to that of indomethacin. While the alcoholic extract of the leaf $(400$ $\mathrm{mg} / \mathrm{kg}$ ) has a maximum activity after 3 hours.

Inhibitory effects of the extracts and fractions on HIV and its enzymes

Investigation of anti HIV, 1 PR and RT inhibitory activities of the extracts and fractions of Grevillea robusta A. Cunn. bark and fruits indicated that some with high activities, while others with moderate activities (Tables 2 and 3). In the primary screening test for anti HIV of the aqueous extract of Grevillea robusta A. Cunn. bark, it was found that the extract inhibit HIV-1 induced cytopathic effect (CPE) in MT-4 cells with a $100 \%$ inhibitory concentration (IC) value $\geq 500 \mu \mathrm{g} / \mathrm{ml}$, and the IC value was $\approx$ half of the respective cytotoxic concentration (CC) value $\geq$ $1000 \mu \mathrm{g} / \mathrm{ml}$. As for HIV-1 PR inhibitory effects, the PR activity was determined by analyzing the reaction mixture in the presence or absence of the two extracts using HPLC method. Both extracts were found to have moderate HIV-1 PR inhibitory effect (Table 3). From Table (2) it is concluded that the EtOAc-soluble fraction of Grevillea robusta bark showed the highest HIV-1 RT inhibitory activity $(86.1 \pm 6.9)$ at conc. $200 \mu \mathrm{g} / \mathrm{ml}$, while the butanol fraction showed a moderate activity (47.7 \pm 5.8).

From Table (3) it can be concluded that the methanol and aqueous extracts of the bark have a moderate HIV-1PR inhibitory activity.

\section{Acknowledgement}

To Prof. Dr. Masao Hattori, Toyama Medical and Pharmaceutical university for carrying out the HIV, HIV-1 PR and HIV- RT inhibitory activity tests.

\section{REFERENCES}

1- Y. M. L. Sharma, Myforest, Forest Department Mysore, 3, 35 (1966).

2- R. J. Streets, "Exotic Forest Trees in British Commonwealth". Clarendon Press, Oxford., 1962, p. 765.

3- Y. R. A. Rao, Bangalore, 25, 329 (1961).

4- M. Takahashi, H. Fuchino, M. Satake, Y. Agatsuma and S. Sekita, Biol. Pharm. Bull, Jun 27, 921 (2004).

5- A. S. Ahmed, Ph. D. thesis, Faculty of Pharmacy, Assiut University (1997). 
6- A. S. Ahmed, N. Norio, R. M. Meselhey, A. M. Makboul, El. E. Nasr. and H. Masao, Phytochemistry, 53, 149 (2000).

7- A. S. Ahmed, Bull. Fac. Pharm. Cairo Uni., 40, 245 (2002).

8- V. Emir, F. Manuel, G. D. Jesús, G. Antonio and B. Jaime, Planta Med., 60, 395 (1994).

9- O. Torku, M. Haruyo, M. Motoko, U. Nboru, T. Ines, A. Yasmina, M. Hirosugu, $\mathrm{H}$. Masao, N. Tsuneo, G. Mahabir and C. Mireya, J. Tradi. Med., 11, 188 (1994).

10- C. D. Barros, E. L. G. Fonseca, O. R. Gottlieb and S. J. Goncalves, Phytochemistry, 9, 447 (1970).
11- T. Higuchi, C. Satake and M. Hirobe, J. Am. Chem. Soc., 117, 8879 (1995). (Supplemental Page 2).

12- J. Ellery, E. Olusegun and D. G. I. Kingston, J. Nat. Prod., 44, 493 (1981).

13- E. Breitmaier and W. Voelter, "Carbon-13 NMR Spectroscopy" $3^{\text {rd }}$ Ed., New York NY: VCH, 1987, pp. 257, 261.

14- Z. Xi-Ning, O. Hideaki, I. Toshinori, H. Eiji, T. Anki and T. Yoshio, Phytochemistry, 49, 2149 (1998).

15- Ç. Ihsan and K. Hasan, ibid., 65, 2619 (2004).

16- N. Hiroaki, S. Hiroshi, M. Takashi, C. Masao and M. Hiroshi, ibid., 29, 3303 (1990). 